\title{
CURRENT STATUS OF TRANSGENIC COTTON-UTILITY OF GENOTYPE INDEPENDENT IN PLANTA APPROACHES FOR THE GENERATION OF TRANSGENICS
}

\author{
Kesiraju Karthik \\ Amity Institute of Biotechnology \\ Amity University Haryana, Manesar, Gurugram
}

Received: 22.11.2020

Revised: 08.12.2020

Accepted: 28.12.2020

\begin{abstract}
Cotton (Gossypium spp.), is a mercantile crop plant is grown for its fluffy fiber and cotton seed oil in around 70 countries worldwide. Cotton is an economically important crop, shows erratic productivity under rain feed conditions; it is bogged down with many biotic and abiotic stresses. Due to lack of resistant germplasm, crop improvement through conventional breeding practices has been lagging. Genetic engineering offers numerous protocols to engineer plants to overcome stress. Biotechnological intervention for cotton improvement has begun three decades ago. The recalcitrance of cotton to tissue culture has been the major constraint for in vitro regeneration. Alternate methods that evade tissue culture regeneration steps have thus been envisaged. Till date there are very few standardized protocols that can be employed to develop transgenics in a genotype independent manner. Thus, genotype independent in planta transformation strategies have gained momentum in the present days, but reproducibility of reported protocols remains an amigna in many cases. In planta transformations holds prominence due to viability and ease in generation of transgenic cotton plants with in less time. This review focuses on grouping efforts made by different research groups in this senior. Several reports and standardizations have been focused that reports development of transgenic cotton.
\end{abstract}

Keywords: Transgenic cotton, invitro regeneration, genotype independent, in planta transformation, genetic engineering.

\section{INTRODUCTION}

The prosperity of Indian economy depends on positive strides in agricultural and industrial sectors. Sustainable agriculture is the need of the hour in the context of global and liberalization trends. Crop production encounters various biotic and abiotic stresses particularly in the arid and semiarid regions (Mohapatra and Saha, 2019). Cotton is a major fibre crop of global importance and has high commercial value. Cotton is grown in about 80 countries across the world and is planted in an average area of 329.49 lakh hectares. India holds $1^{\text {st }}$ rank in cotton production and contributes to $33.23 \%$ of total world produce followed by China contributing $16.02 \%$. The countries of USA, Pakistan, Uzbekistan and Brazil rank the next positions respectively (Directorate of Cotton Development
Government of India, 2017), where climatic conditions suit the natural growth requirements for cotton. Cotton is the most important fibre crop and is the basic input to the textile industry. India has the largest cotton growing area in the world with about 9.6 million hectares under cultivation accounting for one-fourth of the global cotton area. Cotton cultivation surpasses periods of hot and dry weather and adequate moisture obtained through irrigation. Cotton is harvested as 'seed cotton' which is then 'ginned' to separate the seed and lint. The long 'lint' fibres are further processed by spinning to produce yarn which is knitted or woven into fabrics.

Rainfed cotton production has significant contribution towards erratic cotton productivity. It is obvious that growth and development of cotton has to face one or other stress

*Corresponding author: kartikkesiraju@gmail.com 
entities under rainfed situation. Cotton physiology portrays unique indeterminate growth habits with longer crop duration which make cotton vulnerable to abiotic stress influences from emergence to senescence. The adverse effects on the ongoing physiological processes may affect yield projection trends leading to production lapses. The various abiotic stress factors affect cotton growth, development and yield; their occurrence may be erratic or specific and their intensity may be varying in adversity.

DNA sequence data suggests that Gossypium genus arose about 1020 million years ago (Wendel \& Albert, 1992; Seelanan et al., 1997). However evidences do not confirm the place of its origin exactly. West-central and southern Mexican regions with 18 species, North-east Africa and Arabia with 14 species and Australia with 17 species are known to be the primary centres of diversity. Cotton species, Gossypium arboretum and Gossypium herbaceum are diploid, indigenous to Asia and Africa and are confined to the "old world cotton". American cotton Gossypium hirsutum and Egyptian cotton Gossypium barbadense are amphidiploids (tetraploid, 2n=52), with centres of variability in Mexico, Central America and South America, belong to "new world cotton". G.hirsutum and G.barbadense are the two species most commonly cultivated on commercial scale. G.hirsutum is also kown as upland cotton comprising of $90 \%$ of world plantings, it was introduced into India during the $18^{\text {th }}$ century A.D. (Hutchinson, 1959).

Conventional cotton breeding takes advantage of desirable alleles that exist in the cultivated germplasm of the same or a different Gossypium species. Natural variations existing within the genus of any plant species affords for continuous genetic improvement. Although improvement of lint yield remains the top priority in cotton breeding, weed control in cotton is more difficult. Cotton yield losses due to pests, including insects, are severe. Genetic traits within cotton can provide little insect resistance, but not satisfactory for controlling them. Thus the lack of dominant gene pool in cultivated germ plasma. This has stipulated for novel traits that can be introduced from other species to cotton for effective pest control through genetic engineering.

\section{Biotechnological invasions for cotton improvement}

Transgenic crops are an illustration of trait improvement. Transgenic technology has emerged as an awful tool for crop improvement with an assortment of techniques and strategies being used for gene delivery in crop plants as well as in cotton for its improvement (Birch 1997). Genetic engineering offers the feasibility to selectively introduce one or more genes that would escort the development of transgenic cotton to overcome both biotic and abiotic stresses (Oerke 2006). The most profound and major bottlenecks for deployment of genes through transgenesis has been the amenability of the commercially important or target crops to regeneration protocols. Not all economically important crop plants are regenerationfriendly to regeneration protocols. Since the reproducibility of reported regeneration protocol becomes an amigna in the same species, the search of alternative transformation approaches have become vauge. These recalcitrant plants have been labelled as "difficult to regenerate” plants. Several techniques and strategies are being employed to accommodate foreign genes delivery into plant genome; using the only natural biological plant transformation agent Agrobacterium tumefaciens which can aid in gene transfer. Most conventional plant transformation protocols use, Agrobacterium to engineer the plant genome with either tissue culture approaches or inplanta approaches. For many plant species that are amenable to transformation and regeneration by $A$. tumefaciens, T-DNA-directed gene transfer remains the method of choice because of its ease, efficient transgene delivery and integration into the host genome. Compared to direct DNA transfer methods, Agrobacterium-mediated transformations are most sophisticated and established method of transformation for most of the higher plants. In addition, this method does not demand specialized equipment or associated consumables for transformation.

\section{Embryogenesis and Somatic embryogenesis in cotton}

The first report of development of cotton transgenics was reported in 1987. Somatic embryogenesis (SE) and embryogenesis was used for the development of cotton by regeneration based approaches. Transgenics in cotton cultivar Coker 210 (Firoozabady et al. 1987) and Coker 312 (Umbeck et al. 1987) are the initial reports of transgenics in cotton. The genotype plays a major role in regeneration of cotton. Screening of about 38 cultivars belongigng to different cotton races ( $G$. hirsutum, $G$. barbadens and G. Arborium) with different hormonal regimes showed that only Coker 312 showed highest frequency of embryogenesis in all combinations, followed by Coker 304, Coker 315, T 25 and Coker 310 (Trolinder and Xhixian 1989). Thus Cooker 312 has become the most preferable genotype, followed by Zhongmiansuo-35 and YZ-1 for the production of transgenics through regeneration based approaches. Several research groups have proposed various media compositions and used different explants for cotton for transgenic development. Some studies have been listed below. 
Table 1: List of various studies that developed transgenic cotton using different explants.

\begin{tabular}{|c|c|c|}
\hline Genotype/cultivar & Explant & References \\
\hline G. hirsutum & Cotyledon & Davidonis and Hamilton. 1983 \\
\hline G. klotzschianum Anderss & Hypocotyl & Finer and Smith. 1984 \\
\hline $\begin{array}{l}\text { G. hirsutum L. cv. Coker, 201, 208, 310, 315, } \\
\text { DES 56, GSA 71, Lankart 57, Paymaster 145, } \\
\text { Quapaw, RC10-3, Stroman } 254 .\end{array}$ & Hypocotyl & Shoemaker et al. 1986 \\
\hline $\begin{array}{l}\text { G. hirsutum L. cv. Coker 312, T 25, T 169, } \\
\text { Paymaster 303,784. }\end{array}$ & Hypocotyl & Trolinder and Goodin. 1987 \\
\hline G. hirsutum L. cv. Coker 310 & Cotyledon & Finer. 1988 \\
\hline $\begin{array}{l}\text { G. hirsutum L. cv. Stoneville 215, 453, 506, } \\
\text { Acala, Lu, Coker 5110, 313, 100s, 304, 315, } \\
\text { 310, 312, 15, Paymaster 303, 784, } 145 . \\
\text { G.arboreum L. var. Jyoti }\end{array}$ & Hypocotyl & Trolinder and Xhixian. 1989 \\
\hline $\begin{array}{l}\text { G. hirsutum L. cv. Coker 201, 310, 315, 4360, } \\
\text { GSA } 71,75,78 \text {,CSC } 25 \text {, G } 8160\end{array}$ & Cotyledon, hypocotyl, leaf sections & Firoozabady and DeBoer. 1993 \\
\hline G. hirsutum L. cv. Coker 201, CRI 12 & Cotyledon, hypocotyl & Zhang et al. 2000 \\
\hline G. hirsutum L. cv. Deltapine 90, GB 35, B126 & Cotyledon, hypocotyl & Sakhanokho et al. 2001 \\
\hline $\begin{array}{l}\text { G. hirsutum L. cv. Coker 312, Acala cv. Maxxa, } \\
\text { Riata, Ultima }\end{array}$ & Hypocotyl & Mishra et al. 2003 \\
\hline G. hirsutum L. cv. Coker 310 & Hypocotyl, cotyledon & Kumria et al. 2003 \\
\hline $\begin{array}{l}\text { G. hirsutum L. cv. Ekang 3, 4, 6, 8, 9, 10, } \\
\text { Emian 22, Ejing B1, B11, Coker } 201\end{array}$ & Hypocotyl & Wu et al. 2004 \\
\hline G. hirsutum L. cv. Nazilli M 503, Nazilli 143 & Shoot apices, hypocotyl, nodes & Aydin et al. 2004 \\
\hline G. hirsutum L. cv. Coker 312 & Hypocotyl, cotyledon & Kumar et al. 2004 \\
\hline \multicolumn{3}{|l|}{ G. hirsutum L. cv. SH 131, Khandwa 2.} \\
\hline G. arborium L. cv. Sarvottam, Jawahartapti & Hypocotyl, cotyledon & Khan et al. 2006 \\
\hline G. hirsutum L. cv. Coker & Hypocotyl & Aydin et al. 2006 \\
\hline G. hirsutum L. & Hypocotyl, immature zygotic embryos & Hussain et al. 2009 \\
\hline $\begin{array}{l}\text { G. hirsutum L. cv. Khandwa, RS 810, Pusa 37, } \\
\text { Pusa 26, Stoneville, F1084, CA } 1193\end{array}$ & Cotyledonary node with shoot apex & Gupta et al. 1997 \\
\hline \multicolumn{3}{|l|}{ G. arborium L. cv. Shyamly, Lolnt } \\
\hline $\begin{array}{l}\text { G. hirsutum L. cv. Anjali and } \\
\text { G. hirsutum L. cv. LRK } 516\end{array}$ & $\begin{array}{l}\text { Cotyledonary node with } \\
\text { shoot apex devoid of cotyledons }\end{array}$ & Agrawal et al. 1997 \\
\hline $\begin{array}{l}\text { G. hirsutum L. cv. Stoneville 7A and } \\
\text { Paymaster HS26 }\end{array}$ & $\begin{array}{l}\text { Shoot apices Secondary leaf node } \\
\text { Cotyledonary nodes }\end{array}$ & Hemphill et al. 1998 \\
\hline $\begin{array}{l}\text { NCS 3, NA 1325, NA 920, NHH 390, DCH 32, } \\
\text { Anjali, Srisailam, PMC, LRA, MCU } 5\end{array}$ & Shoot tip & Tripathy and Reddy. 2002 \\
\hline $\begin{array}{l}\text { G. hirsutum L. cv. MCU-5, DCH 32, } \\
\text { Coker 310FR }\end{array}$ & Shoot tip & Satyavathi et al. 2002 \\
\hline G. hirsutum L. cv. NIAB 999 & $\begin{array}{l}\text { Cotyledonary node with } \\
\text { both cotyledons }\end{array}$ & Rauf et al. 2005 \\
\hline G. hirsutum L. cv. Barac (67)B & $\begin{array}{l}\text { Cotyledonary node devoid of } \\
\text { cotyledons and apical meristems }\end{array}$ & Abdellatef and Khalafalla. 2007 \\
\hline G. hirsutum L. cv. Bharani, Durga, JKCH 99 & Hypocotyl & Divya et al. 2008 \\
\hline $\begin{array}{l}\text { G. hirsutum L. hybrid H8 } \\
\text { G. hirsutum L. Khandwa } 2 \\
\text { G. arborium L. cv. BD ,1BD 6, Sarvottam }\end{array}$ & Cotyledonary node & Obembe et al. 2011 \\
\hline
\end{tabular}




\begin{tabular}{|l|l|l|}
\hline G. hirsutum L. cv. MCU 11 & $\begin{array}{l}\text { Cotyledonary node devoid of } \\
\text { cotyledons }\end{array}$ & Mushke et al. 2012 \\
\hline G. hirsutum L.cv. NA 1325 & Embryo axis & Pathi and Tuteja. 2013 \\
\hline G. hirsutum L. cv. NC 601 & Cotyledonary node & Chakravarthy. 2013 \\
\hline
\end{tabular}

Source: Jutur et al., 2015.

\section{In planta transformation in cotton}

Tissue culture based transformations are tedious, time consuming, lead to variations in plant morphology and poor quality of seed pool that may not be viable to carry the modified trait to the subsequent generations. Development of a large number of uniform plants in short time with less labour efforts and minimal reagent requirements is the triumph of in planta transformations for trait modification in recalcitrant plant species. These tissue cultureindependent in planta techniques were first initiated in Arabidopsis thaliana and has thrown new insight in the scientific community to development high throughput transformation protocols with the aid of Agrobacterium. In planta transformation methods in Arabidopsis such as "clip 'n' squirt” and vacuum infiltration have been successfully used by many researchers.

Table 2: In planta approach based Agrobacterium mediated gene transfer for transgenic cotton developed.

\begin{tabular}{|l|l|l|l|}
\hline Genotype/cultivar & Transformed gene(s) & Method of transformation & References \\
\hline Zheda B & hptII, uidA and ntII, uidA & $\begin{array}{l}\text { Ovarian injection following } \\
\text { pollination }\end{array}$ & Bibi et al. 2013 \\
\hline Sahana and BC 68-2 & cry1Ac, cry1Ia5, cry1Aa3 and cry1F & Stigmatic surface treatment & Mogali et al. 2013 \\
\hline Xinluzao 019 & susy, gus and nptII & Pollen mediated transformation & Zhang et al. 2008 \\
\hline NC 71 & uidA and nptII & Meristem transformation & Keshamma et al. 2008 \\
\hline Khandwa 2, Anjali and Coker 310 & uidA & Meristem transformation & Kumar et. al. 2013 \\
\hline P8-6 & hptii: gfp & Meristem transformation & \\
\hline Meristem transformation & Kesiraju et al., 2020 & & \\
\hline P8-6 & nptii:CP4-EPSPS & & Karthik et al., 2020 \\
\hline
\end{tabular}

Several research groups have adopted diverse in planta transformation strategies for the generation of transgenic cotton (Rajasekaran et al., 2005; Zhang et al. 2009; Tian et al., 2010; Jin et al., 2012; Bibi et al. 2013; Mogali et al., 2013; Pathi and Tuteja., 2013; Vajhala et al., 2013; Kalbande and Patil et al., 2016; Guo et al. 2018). Though apical meristem has been the preferred target in most of these studies, the mode of infection has been different. However, the hypothesis of the standardized protocols have been the introduction of transgenes into the differentiating meristematic cells leading to concomitant transgenic expression in the shoots, ultimately resulting in their inheritance (Maher et al., 2020).

\section{CONCLUSIONS}

Tremendous progress has been made in the development of transgenic cotton. Both Agrobacterium mediated and direct gene delivery methods have been developed by many research groups across the world. Despite of such advances also, genotype dependency is still considered as major constraint and splendors the potential of transformation approaches in transgenic development. Recent reports on cotton improvement have shown that apical meristem targeted in planta strategy can tackle the problem of genotype dependency (Karthik et al., 2020; Kesiraju et al., 2020). As this in planta transformation method was previously reported by Keshamma et al. 2008 (using GUS gene as a screenable marker) in a different cultivar, the recent report of successful deployment of the same technique was reported by Karthik et al., 2020 in two different reports, where GFP was used in one study and a herbicide tolerance gene CP4-EPSPS was used in another study in the same genotype.

Introduction of genetic changes into meristems reported concomitant transgenic expression in the shoots which later on produced flowers and seeds, ultimately transmitting transgenes and gene edits to the next generation (Maher et al., 2020). Agrobacterium mediated in planta transformation approaches using apical meristem 
has been the preferred target for successful develoyment of transgenics as reported by most of the recent studies (Maher et al., 2020; Tyagi et al., 2020; Zlobin et al., 2020).

In planta transformation transformation of A. thaliana was made feasible by vacuum filtration which was considered as a tedious task before (Clough and Bent 1998). These in planta methodologies are reliable and reproducible also. Moreover this apical meristem targeted in planta transformation has also been proved to be genotype independent. The utility of this protocol was investigated in different crops (Kesiraju et al., 2017) and its genotype independent nature was demonstrated crops like capsicum, pegion pea, groundnut (Karthik et al., 2020). Thus this protocol has the power to speed up cotton transformation programmers efficiently. Transgenic cotton for herbicide resistance and insect resistance has become a reality in achieving enormous yield gains. However, further development of insect resistant cotton with different genes and modes of actions is the need of the hour. Hope this strategy would also be useful for the demonstration and validation of RNA interference and CRISPR based genome editing strategies in cotton and aid in crop improvement.

\section{REFERENCES}

1. Abdellatef, E.L.T.A.Y.B. and Khalafalla, M.M., 2007. Adventitious shoot and plantlet formation in medium staple cotton cultivar (Gossypium hirsutum L. cv Barac [67] B). Int. J. Agric. Biol, 6, pp.913-916.

2. Agrawal, D.C., Banerjee, A.K., Kolala, R.R., Dhage, A.B., Kulkarni, A.V., Nalawade, S.M., Hazra, S. and Krishnamurthy, K.V., 1997. In vitro induction of multiple shoots and plant regeneration in cotton (Gossypium hirsutum L.). Plant Cell Reports, 16(9), pp.647-652.

3. Aydin, Y., Talas-Ogras, T., Ipekçi-Altas, Z. and Gözükirmizi, N., 2006. Effects of brassinosteroid on cotton regeneration via somatic embryogenesis. Biologia, 61(3), pp.289-293.

4. Aydin, Y.I.L.D.I.Z., Ipekci, Z., Talas-Oğraş, T., Zehir, A., Bajrovic, K. and Gozukirmizi, N., 2004. High frequency somatic embryogenesis in cotton. Biologia plantarum, 48(4), pp.491-495.

5. Bibi, N., Fan, K., Yuan, S., Ni, M., Ahmed, I.M., Malik, W. and Wang, X., 2013. An efficient and highly reproducible approach for the selection of upland transgenic cotton produced by pollen tube pathway method. Australian Journal of Crop Science, 7(11), p.1714.

6. Birch, R.G., 1997. Plant transformation: problems and strategies for practical application. Annual review of plant biology, 48(1), pp.297-326.
7. Chakravarthy, V.S., 2013. Rapid production of multiple shoots from cotyledonary node explants of an elite cotton (Gossypium hirsutum L.) variety. Research in Plant Biology, 3(5).

8. Clough, S.J. and Bent, A.F., 1998. Floral dip: a simplified method for Agrobacterium-mediated transformation of Arabidopsis thaliana. The plant journal, 16(6), pp.735-743.

9. Davidonis, G.H. and Hamilton, R.H., 1983. Plant regeneration from callus tissue of Gossypium hirsutum L. Plant Science Letters, 32(1-2), pp.89-93.

10. Directorate of Cotton Development Government of India. (2017). Status Paper of Indian Cotton. Nagpur. Accessed on July 27, 2019.

11. Divya, K., Anuradha, T.S., Jami, S.K. and Kirti, P.B., 2008. Efficient regeneration from hypocotyl explants in three cotton cultivars. Biologia Plantarum, 52(2), pp.201-208.

12. Finer, J.J. and Smith, R.H., 1984. Initiation of callus and somatic embryos from explants of mature cotton (Gossypium klotzschianum Anderss). Plant cell reports, 3(1), pp.41-43.

13. Finer, J.J., 1988. Plant regeneration from somatic embryogenic suspension cultures of cotton (Gossypium hirsutum L.). Plant Cell Reports, 7(6), pp.399-402.

14. Firoozabady, E. and DeBoer, D.L., 1993. Plant regeneration via somatic embryogenesis in many cultivars of cotton (Gossypium hirsutum L.). In Vitro Cellular \& Developmental Biology-Plant, 29(4), pp.166-173.

15. Firoozabady, E., DeBoer, D.L., Merlo, D.J., Halk, E.L., Amerson, L.N., Rashka, K.E. and Murray, E.E., 1987. Transformation of cotton (Gossypium hirsutum L.) by Agrobacterium tumefaciens and regeneration of transgenic plants. Plant Molecular Biology, 10(2), pp.105-116.

16. Guo WF, Wang KY, Nan Wang, Jun LI, Li GQ, Liu DH (2018) Rapid and convenient transformation of cotton (Gossypium hirsutum L.) using in planta shoot apex via glyphosate selection. J Integr Agric.17: 21962203.

17. Gupta, S.K., Srivastava, A.K., Singh, P.K. and Tuli, R., 1997. In vitro proliferation of shoots and regeneration of cotton. Plant cell, tissue and organ culture, 51(2), pp.149-152.

18. Hemphill, J.K., Maier, C.G.A. and Chapman, K.D., 1998. Rapid in-vitro plant regeneration of cotton 
(Gossypium hirsutum L.). Plant Cell Reports, 17(4), pp.273-278.

19. Hussain, S.S., Rao, A.Q., Husnain, T. and Riazuddin, S., 2009. Cotton somatic embryo morphology affects its conversion to plant. Biologia Plantarum, 53(2), pp.307-311.

20. Hutchinson, G.E., 1959. Homage to Santa Rosalia or why are there so many kinds of animals?. The American Naturalist, 93(870), pp.145-159.

21. Jin SX, Liu GZ, Zhu HG, Yang XY, Zhang XL (2012) Transformation of upland cotton (Gossypium hirsutum L.) with $g f p$ gene as a visual marker. J Integr Agric. 11: 910-919.

22. Juturu, V.N., Mekala, G.K. and Kirti, P.B., 2015. Current status of tissue culture and genetic transformation research in cotton (Gossypium spp.). Plant Cell, Tissue and Organ Culture (PCTOC), 120(3), pp.813-839.

23. Kalbande BB, and Patil AS (2016) Plant tissue culture independent Agrobacterium tumefaciens mediated Inplanta transformation strategy for upland cotton (Gossypium hirsutum). J Genet Eng Biotechnol, 14: 9-18.

24. Karthik K, Nandiganti M, Thangaraj A, Singh S, Mishra P, Sharma M, and Sreevathsa R (2020) Transgenic cotton (Gossypium hirsutum L.) to combat weed vagaries: utility of an apical meristem-targeted in planta transformation strategy to introgress a modified CP4-EPSPS gene for glyphosate tolerance. Front Plant Sci.11, 768.

25. Keshamma E, Rohini S, Rao KS, Madhusudhan B, Kumar MU (2008) Tissue culture-independent in planta transformation strategy: an Agrobacterium tumefaciens-mediated gene transfer method to overcome recalcitrance in cotton (Gossypium hirsutum L.). J Cotton Sci.

26. Kesiraju K, Sreevathsa R (2017) Apical MeristemTargeted In Planta Transformation Strategy: an Overview on its utility in Crop Improvement. Agri Res and Tech.

27. Kesiraju, K., Mishra, P., Bajpai, A., Sharma, M., Rao, U. and Sreevathsa, R., 2020. Agrobacterium tumefaciens-mediated in planta transformation strategy for development of transgenics in cotton (Gossypium hirsutum L.) with GFP as a visual marker. Physiology and Molecular Biology of Plants, pp.1-9.

28. Khan, T., Singh, A.K. and Pant, R.C., 2006. Regeneration via somatic embryogenesis and organogenesis in different cultivars of cotton
(Gossypium spp.). In Vitro Cellular \& Developmental Biology-Plant, 42(6), pp.498-501.

29. Kumar, S., Dhingra, A. and Daniell, H., 2004. Stable transformation of the cotton plastid genome and maternal inheritance of transgenes. Plant molecular biology, 56(2), pp.203-216.

30. Kumar, V., Joshi, S.G., Bell, A.A. and Rathore, K.S., 2013. Enhanced resistance against Thielaviopsis basicola in transgenic cotton plants expressing Arabidopsis NPR1 gene. Transgenic research, 22(2), pp.359-368.

31. Kumria, R., Sunnichan, V.G., Das, D.K., Gupta, S.K., Reddy, V.S., Bhatnagar, R.K. and Leelavathi, S., 2003. High-frequency somatic embryo production and maturation into normal plants in cotton (Gossypium hirsutum) through metabolic stress. Plant cell reports, 21(7), pp.635-639.

32. Maher MF, Nasti RA, Vollbrecht M, Starker CG, Clark MD, Voytas DF (2020) Plant gene editing through de novo induction of meristems. Nat Biotechnol.

33. Mishra, C., Allen, P., McCarthy, T.O.M., Madhusudan, M.D., Bayarjargal, A. and Prins, H.H., 2003. The role of incentive programs in conserving the snow leopard. Conservation Biology, 17(6), pp.1512-1520.

34. Mogali SC, Khadi BM, Kategeri IS (2013) High efficiency transformation protocol for two Indian cotton (Gossypium hirsutum) varieties via pollen tube pathway. Ind J Agric Sci. 83: 949-952.

35. Mohapatra L, Saha G (2019) Cotton Farming in India: Alternative Perspectives and Paradigms. In Amar KJR Nayak (eds) Transition Strategies for Sustainable Community Systems, The Anthropocene: Politik-Economics-Society-Science, $1^{\text {st }}$ edn. Springer cham. Switzerland, pp 195-213.

36. Mushke, R., Sultana, T. and Pindi, P.K., 2012. High frequency regeneration and multiple shoot induction in Indian cotton (Gossypium hirsutum L.) cultivar. Research Journal of Agricultural Sciences, 3(5), pp.1109-1112.

37. Obembe, O.O., Khan, T. and Popoola, J.O., 2011. Use of somatic embryogenesis as a vehicle for cotton transformation. Journal of Medicinal Plants Research, 5(17), pp.4009-4020.

38. Oerke, E.C., 2006. Crop losses to pests. The Journal of Agricultural Science, 144, p.31.

39. Pathi KM, and Tuteja N (2013) High-frequency regeneration via multiple shoot induction of an elite recalcitrant cotton (Gossypium hirsutum L. cv 
Narashima) by using embryo apex. Plant Signal Behav. 8: e22763.

40. Pathi, K.M. and Tuteja, N., 2013. High-frequency regeneration via multiple shoot induction of an elite recalcitrant cotton (Gossypium hirsutum L. cV Narashima) by using embryo apex. Plant Signaling \& Behavior, 8(1), p.e22763.

41. Rajasekaran, K., Cary, J.W., Jaynes, J.M. and Cleveland, T.E., 2005. Disease resistance conferred by the expression of a gene encoding a synthetic peptide in transgenic cotton (Gossypium hirsutum L.) plants. Plant Biotechnology Journal, 3(6), pp.545-554

42. Rauf, S.A.E.E.D., Khan, T.M. and Nazir, S.H.A.H.I.D., 2005. Combining ability and heterosis in Gossypium hirsutum L. Int. J. Agri. Biol, 7(1), pp.109-113.

43. Sakhanokho, H.F., Zipf, A., Rajasekaran, K., Saha, S. and Sharma, G.C., 2001. Induction of highly embryogenic calli and plant regeneration in upland (Gossypium hirsutum L.) and Pima (Gossypium barbadense L.) cottons. Crop Science, 41(4), pp.12351240.

44. Satyavathi, V.V., Prasad, V., Lakshmi, B.G. and Sita, G.L., 2002. High efficiency transformation protocol for three Indian cotton varieties via Agrobacterium tumefaciens. Plant science, 162(2), pp.215-223.

45. Seelanan, T., Schnabel, A. and Wendel, J.F., 1997. Congruence and consensus in the cotton tribe (Malvaceae). Systematic Botany, pp.259-290.

46. Shoemaker, R.C., Couche, L.J. and Galbraith, D.W., 1986. Characterization of somatic embryogenesis and plant regeneration in cotton (Gossypium hirsutum L.). Plant Cell Reports, 5(3), pp.178-181.

47. Tian ZC, Shen JW, Jun Z, Wang ZG, Tian ZZ (2010) Pistil drip following pollination: a simple in planta Agrobacterium-mediated transformation in cotton. Biotechnol Lett.

48. Tripathy, S.U.C.H.E.T.A. and Reddy, G.M., 2002. In vitro callus induction and plantlet regeneration from Indian cotton cultivars. Plant Cell Biotechnol. Mol. Biol,3(3\&4), pp.137-142.

49. Trolinder, N.L. and Goodin, J.R., 1987. Somatic embryogenesis and plant regeneration in cotton (Gossypium hirsutum L.). Plant Cell Reports, 6(3), pp.231-234.
50. Trolinder, N.L. and Xhixian, C., 1989. Genotype specificity of the somatic embryogenesis response in cotton. Plant Cell Reports, 8(3), pp.133-136.

51. Trolinder, N.L. and Xhixian, C., 1989. Genotype specificity of the somatic embryogenesis response in cotton. Plant Cell Reports, 8(3), pp.133-136.

52. Tyagi, S., Kesiraju, K., Saakre, M., Rathinam, M., Raman, V., Pattanayak, D. and Sreevathsa, R., 2020. Genome editing for resistance to insect pests: an emerging tool for crop improvement. ACS omega, 5(33), pp.20674-20683.

53. Umbeck, P., Johnson, G., Barton, K. and Swain, W., 1987. Genetically transformed cotton (Gossypium hirsutum L.) plants. Bio/technology, 5(3), pp.263-266.

54. Vajhala CS, Sadumpati VK, Nunna HR, Puligundla SK, Vudem DR, Khareedu VR (2013) Development of transgenic cotton lines expressing Allium sativum agglutinin ( $A S A L)$ for enhanced resistance against major sap-sucking pests. PLoS One. 8: e72542.

55. Wendel, J.F. and Albert, V.A., 1992. Phylogenetics of the cotton genus (Gossypium): character-state weighted parsimony analysis of chloroplast-DNA restriction site data and its systematic and biogeographic implications. Systematic Botany, pp.115-143.

56. Wu, K., 2007. Monitoring and management strategy for Helicoverpa armigera resistance to Bt cotton in China. Journal of Invertebrate Pathology, 95(3), pp.220-223.

57. Yan, J., He, C., Wang, J., Mao, Z., Holaday, S.A., Allen, R.D. and Zhang, H., 2004. Overexpression of the Arabidopsis 14-3-3 protein GF14 $\lambda$ in cotton leads to a "stay-green" phenotype and improves stress tolerance under moderate drought conditions. Plant and Cell Physiology, 45(8), pp.1007-1014.

58. Zhang, B.H., Liu, F. and Yao, C.B., 2000. Plant regeneration via somatic embryogenesis in cotton. Plant Cell, Tissue and Organ Culture, 60(2), pp.89-94.

59. Zhang, H., Zhao, F., Zhao, Y., Guo, C., Li, C. and Xiao, K., 2009. Establishment of transgenic cotton lines with high efficiency via pollen-tube pathway. Frontiers of Agriculture in China, 3(4), p.359.

60. Zlobin, N.E., Lebedeva, M.V. and Taranov, V.V., 2020. CRISPR/Cas9 genome editing through in planta transformation. Critical Reviews in Biotechnology, 40(2), pp.153-168. 